\title{
The entrepreneurial ladder, gender, and regional development
}

\author{
Peter van der Zwan · Ingrid Verheul • \\ A. Roy Thurik
}

Accepted: 1 December 2010/Published online: 3 April 2011

(C) The Author(s) 2011. This article is published with open access at Springerlink.com

\begin{abstract}
Gender differences at five levels of entrepreneurial engagement are explained using country effects while controlling for individual-level variables. We distinguish between individuals who have never considered starting up a business, those who are thinking about it, and nascent, young, and established entrepreneurs. We use a large international dataset that includes respondents from 32 European countries, three Asian countries, and the United States. Findings show that cross-country gender differences are largest in the first and final transitions of the entrepreneurial process. In
\end{abstract}

P. van der Zwan $(\bowtie)$. A. R. Thurik

Centre for Advanced Small Business Economics, Erasmus School of Economics, Erasmus University Rotterdam, P.O. Box 1738, 3000, DR, Rotterdam, The Netherlands e-mail: vanderzwan@ese.eur.nl

A. R. Thurik

e-mail: thurik@ese.eur.nl

P. van der Zwan · A. R. Thurik

EIM Business and Policy Research (a Panteia company), P.O. Box 7001, 2701, AA, Zoetermeer, The Netherlands

I. Verheul

Centre for Entrepreneurship and New Business Venturing Rotterdam School of Management, Erasmus University Rotterdam, P.O. Box 1738, 3000, DR, Rotterdam,

The Netherlands

e-mail: iverheul@rsm.nl

A. R. Thurik

GSCM-Montpellier Business School, Montpellier, France particular, some European transition economies are characterized by relatively low propensities of women to convert start-up considerations into startup activities and low survival rates of businesses started by women.

Keywords Entrepreneurship · Determinants · Gender · International

JEL Classifications $\mathrm{H} 10 \cdot \mathrm{J} 23 \cdot \mathrm{L} 26 \cdot \mathrm{M} 13 \cdot \mathrm{R} 12$

\section{Introduction}

Policy makers and academics acknowledge the importance of entrepreneurship for regional performance (Audretsch et al. 2008; Carree and Thurik 2010; Van Stel and Suddle 2008), for example in terms of competitiveness (Kitson et al. 2004; European Commission 2009). According to Fritsch (2011), new venture creation affects regional development both directly and indirectly. Directly, new firms lead to new "capacities" in the economic environment. That is, newcomers develop and grow thereby contributing to the local economy via, e.g., employment creation. Indirectly, new business formation affects the competitiveness and welfare of regions by several mechanisms, including competition pressure that may lead to the closure or improved performance of inefficient incumbents (selection 
mechanism), the introduction of radical innovations, and the supply of a greater variety of products.

From this perspective it is important to preserve a large pool of potential and aspiring entrepreneurs. One untapped source of entrepreneurial energy is female entrepreneurship. Although women have significantly increased their participation in business start-up activities in recent years, they still systemically lag behind men regarding business ownership in most parts of the world (De Bruin et al. 2006; Langowitz and Minniti 2007). Triggering women to engage in entrepreneurship can be an important governmental instrument to foster the entrepreneurial climate across countries and regions (Baughn et al. 2006). This "improved" entrepreneurial climate will have benefits for the competitiveness of those countries and regions.

In addition to the economic contribution female entrepreneurs can make by increasing their numbers, they also add variety to the economic process. Indeed, it has been argued that not only is the number of entrepreneurs crucial for economic performance, but that the diversity in entrepreneurship (in terms of gender, ethnicity, education, etc.) plays a role beyond the quantity effect (Verheul and Van Stel 2010). Generally, the diversity of economic actors is an essential driver of economic progress at the level of cities, regions, and national economies (Jacobs 1984; Saviotti 1996; Florida 2002; Broda and Weinstein 2006). Hence, regions benefit when conditions are such that a diverse group of individuals is encouraged and able to initiate and develop entrepreneurial activities. This makes it essential to investigate how countries and regions perform in terms of gender differences in entrepreneurial activity.

The entrepreneurial environment and its perception are important in different stages of the entrepreneurial process by facilitating or hindering (potential) female and male entrepreneurs (Kouriloff 2000; Begley et al. 2005; Koellinger et al. 2007). In this paper our objective is to create a better understanding of the importance of the environment in explaining the backward position of women regarding their involvement at different stages of the entrepreneurial process. The distinction between specific stages enables accurate assessment of where in the process women begin to lag behind men. For example, women may underperform in the decision stages or in the action stages of entrepreneurship. We distinguish between five engagement levels in the entrepreneurial process:

- never considered starting a business;

- thinking about starting a business;

- taking steps to start a business (nascent entrepreneurs);

- running a business for less than three years; and

- running a business for more than three years.

The ordering of these engagement levels from no entrepreneurial involvement to established business ownership is referred to as the "entrepreneurial ladder" (Van der Zwan et al. 2010).

As far as we are aware, research explaining the gender gap in entrepreneurship has not made the distinction between stages in the entrepreneurial process. ${ }^{1}$ This empirical neglect is surprising because the theoretical justification for the use of stages in decision-making in general (Ajzen 1991) and in the area of entrepreneurship in particular (Krueger and Carsrud 1993; Krueger et al. 2000) is compelling. When investigating the effect of living in different parts of the world on the size of the gender gap at different stages of the entrepreneurial process, we also take into account important individual-level variables. This approach is consistent with Klapper and Parker (2010) who argue that gender differences in entrepreneurial engagement and performance reflect constraints in the external business environment or differences in voluntary individual choices across genders. The focus of this empirical study will be on establishing gender differences across countries while controlling for many individual-level variables.

To test for regional differences in women's advancement in the entrepreneurial process, we use recent international data for all 27 European Union Member States, selected non-EU European countries (Croatia, Iceland, Norway, Switzerland, Turkey), three Asian countries (China, Japan, South Korea), and the United States. The data originate from the Flash Eurobarometer Survey on Entrepreneurship

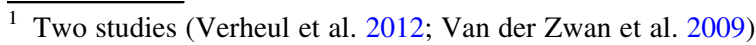
distinguish between stages in the quest for understanding gender differences in entrepreneurship. However, unlike this paper, they establish gender differences at the individual-level and refrain from a comprehensive international comparison.
} 
(No. 283) initiated by the European Commission. The data were collected in December 2009 and January 2010 and are representative of the entire population (over 15 years of age) in all countries. The fact that these data were gathered in a period of global economic downturn implies that one should be careful when comparing findings from this study with results from studies that investigate non-recession periods. Still, most countries and their inhabitants were confronted with similar conditions which should support the comparability of our findings.

The remainder of this paper is organized as follows. In Sect. 2 we review the empirical evidence for the existence of gender differences at specific stages and the transition between stages in the entrepreneurial process. Section 3 is devoted to discussion of differences in the size of the gender gap across countries. Section 4 discusses the data, variables, and methods applied in this study. Subsequently, Sect. 5 presents evidence of the relative gender gap at different stages of the entrepreneurial process across countries. Section 6 summarizes the most important findings and discusses the implications of our study and recommendations for further research within this research domain.

\section{Gender differences in stages of the entrepreneurial process}

The importance of distinguishing between stages in the entrepreneurial process when investigating gender differences in entrepreneurial activity is evident from the empirical literature. The evidence of gender differences in entrepreneurship depends upon the specific stage of the process. In terms of the early "decision" stages of entrepreneurship, relatively few studies have compared entrepreneurial preferences and intentions across gender. The scant evidence shows that women tend to have a lower probability of preferring self-employment over wage employment (Blanchflower et al. 2001; Grilo and Irigoyen 2006) and are characterized by lower intentions to start up a business than men (Crant 1996; Wilson et al. 2004; Zhao et al. 2005). Nevertheless, a study by Gupta et al. (2009) finds that it is not men or women per se but rather the degree to which they perceive themselves as masculine ("male gender identification") that determines entrepreneurial intentions. More specifically, they find that while women and men do not differ regarding their intentions to start up a business, women who perceive themselves as more masculine are characterized by higher entrepreneurial intentions than women with lower male gender identification.

In terms of early-stage entrepreneurial activity (entrepreneurs taking steps to start a business and who run a business for less than 3.5 years), ample evidence is provided by Global Entrepreneurship Monitor data and additional studies based on these data that women are less likely than men to be nascent entrepreneurs. Allen et al. (2008) provide clear evidence of a gender gap in early-stage entrepreneurial activity. On the basis of the Panel Study of Entrepreneurial Dynamics (PSED) data, Reynolds et al. (2004) observe that men are about twice as likely to be involved in nascent entrepreneurial activity. Still, these findings are descriptive and do not take into account important background factors that can differ between women and men. Studies that explain nascent entrepreneurial activity using a multivariate approach furnish mixed results regarding the persistence of the gender gap. For example, controlling for other important individuallevel characteristics (e.g., age, education, income, perception variables), Arenius and Minniti (2005) find that women are significantly less likely to be nascent entrepreneurs than men. However, Minniti and Nardone (2007) show that when women and men are identical in terms of their perceptions, the effect of gender on nascent activity diminishes and almost disappears. This is consistent with Koellinger et al. (2008), who conclude that perceptual differences explain a significant amount of the gender gap in nascent entrepreneurship.

What happens when nascent entrepreneurs have to take the step of starting up and running their company? Are women less likely to take this step toward a mature business than men? Using PSED data, Parker and Belghitar (2006) investigate the outcomes of nascent entrepreneurs (i.e., continuing as nascent entrepreneur, starting up a venture, or giving up completely) after 12 months and find no significant gender differences regarding these outcomes. Hence, this scarce empirical evidence suggests that although women may be less likely to become nascent entrepreneurs, they are not less likely to move to the next step of starting up a business. 
In terms of actual engagement in entrepreneurship there is consensus that women are less likely to run young or mature firms than men (Reynolds et al. 2002; Verheul et al. 2006; Langowitz and Minniti 2007). In our study we want to find out whether women are more or less likely to make the step from young to established firms and to survive the first years of operation. In this respect, Allen et al. (2008) report the existence of a gender gap in new venture survival, for example the likelihood of firm survival beyond 3.5 years is lower for women than for men. Here, different female and male entrepreneurs (and their firms) are compared, but what happens to this gender gap when relevant explanatory variables are taken into account? Boden and Nucci (2000) find that female-owned new firms are somewhat at a disadvantage compared with male-owned new firms. This can be explained by the fact that women have less labor market experience and less financial capital available at start-up. Fairlie and Robb (2009) also find that women entrepreneurs are more likely than men to close their business within a period of four years, but this gender gap diminishes by three quarters when a set of important control variables are taken into account. Similarly, Carter et al. (1997) find that women-owned retail firms have higher odds of discontinuing than male-owned firms, which can be explained in terms of the lower level of resources available to women. Hence, there are situational disadvantages for female entrepreneurs that largely explain their underperformance in terms of survival. This is consistent with studies by Kalleberg and Leicht (1991), Cooper et al. (1994) and Watson (2003), who do not find conclusive evidence that firms owned and managed by women are more likely to go out of business than those of men after controlling for relevant personal and venture characteristics. Ahl (2002, p. 108) concludes that: "The female underperformance hypothesis (...) did not hold when put to rigorous tests accounting for structural factors."

To conclude, these empirical findings inform us about the need to examine stages in the entrepreneurial process to explain gender differences. In an earlier attempt to explain the lower likelihood of women to engage in self-employment, Verheul et al. (2012) show that women are less likely to be engaged in entrepreneurship than men, even when the preference for entrepreneurship is similar across gender.

\section{Gender differences and the environment}

In this study we investigate the size of the gender gap in different stages of the entrepreneurial process across countries. The environment in which individuals are active plays a prominent role in the decision to engage in entrepreneurship (Jack and Anderson 2002; Minniti 2010). Furthermore, there seems to be large cross-country variation in the factors that facilitate or hinder women and men who wish to become entrepreneurs (Verheul et al. 2006).

When grouping countries on the basis of level of economic development, we see that in low-income countries, the gender gap in entrepreneurship is smaller than in more developed countries (Baughn et al. 2006; Minniti et al. 2006). In developing countries, women face entry barriers in the formal labor market and resort to entrepreneurship to escape unemployment or even poverty (Mroczkowski 1997; Welter et al. 2003; Minniti and Naudé 2010). Thus, understanding the role of female entrepreneurship in the context of economic development is especially important (Naudé 2010; Minniti and Naudé 2010). On the basis of GEM data, Minniti et al. (2006) conclude that in high-income countries, men are almost twice as likely to be involved in early-stage entrepreneurial activity or established business ownership, whereas gender differences in early-stage entrepreneurial activity are much less for lowerincome countries.

In addition to the level of economic development, the institutional environment also shapes the conditions for female participation in the labor market and in entrepreneurship. One particular institutional context that is important in explaining entrepreneurial activity is that of transition economies. Few studies have focused on female entrepreneurship in transition countries (Aidis et al. 2007), even though femaleowned firms are said to be of specific importance within the transition context. They can help reduce female unemployment by employing themselves and hiring other women, they can serve as role models that make younger generations aware of alternative occupational opportunities and, finally, they can help to speed up the transition process through their creativity and innovative capacity and through the further development of the private sector. Given their alleged importance, the question that arises is whether the institutional environment in transition 
economies restricts female entrepreneurial activity (Welter et al. 2003). Institutional factors that affect women's engagement in entrepreneurial activity in transition countries include both formal institutions (e.g., legal gender equality, the effect of tax legislation on dual earners, childcare facilities) and informal institutions (e.g., traditional roles, religion, family values, entrepreneurship as masculine activity) (Welter et al. 2003; Aidis et al. 2007). Female entrepreneurship may be inhibited in countries where normative support for female entrepreneurship is lacking because the traditional role of women as caretaker in the household is emphasized (Baughn et al. 2006). ${ }^{2}$ In such countries, child-care facilities are often relatively underdeveloped or non-existent, and therefore, it is more difficult for women to engage in new venture creation (De Bruin et al. 2006).

In terms of stages in the entrepreneurial process, it seems that the problems experienced by women in transition countries mostly occur in the early stages of entrepreneurial activity. For example, the fact that entrepreneurship is mainly seen as an activity undertaken by men may discourage women in transition economies from pursuing an entrepreneurial career. Indeed, according to Welter et al. (2003), cultural norms and values may influence women's start-up intentions in particular. Moreover, the restricted access of women to external resources could also make it harder for women to create a new venture.

Most of the research conducted on entrepreneurship in transition countries has focused on Central and Eastern European (CEE) countries. The entrepreneurial environment in China has been less frequently studied. However, because of the distinctive cultural values and China's current stage of transition, it is important to separate the entrepreneurial environment in this Asian transition economy from that in the CEE and the former Soviet countries. Yang and Li (2008) classify China as a country in an early stage of market transition in which entrepreneurial activity is still constrained by an underdeveloped market and institutional infrastructure. Although the Chinese government has long prevented the establishment of private enterprises (Chow and Fung 1996), entrepreneurs have

\footnotetext{
2 Normative support is measured by the extent to which (1) new business start-ups are acceptable for women, and (2) women are encouraged to be self-employed or entrepreneurs (Baughn et al. 2006, p. 695).
}

emerged since the 1980s. Compared with European transition economies, however, the share of female entrepreneurs in nascent and young entrepreneurial activity in China is relatively high (Baughn et al. 2006; Allen et al. 2008).

Similar to the Chinese case, little is known about the factors that affect the development of female entrepreneurial activity in Japan. Baughn et al. (2006) show that Japan scores almost lowest in terms of the female participation in early-stage entrepreneurship. One explanation for this low participation may lie in the traditional division of labor that is typified by the male-dominated corporate culture (Futagami and Helms 2009). Indeed, Okamuro et al. (2010) find that the relatively low female labor force participation has a negative effect on nascent entrepreneurial activity in Japan (relative to the contribution of this factor in other countries). Related is the fact that support systems for balancing work and family responsibilities are heavily underdeveloped. Although female entrepreneurs have increased their participation in entrepreneurship in Japan, they are still relatively exceptional. Therefore, increasing the number of female entrepreneurs is important for economic growth. A development that is again reinforced by more women who can serve as role models to aspiring young female entrepreneurs in Japan (Lituchy et al. 2003).

\section{Data and methods}

Country differences in entrepreneurial engagement between women and men in several stages of the entrepreneurial process are central to our research. To empirically establish regional gender differences, we use data from the Flash Eurobarometer Survey on Entrepreneurship (No. 283) of the European Commission. ${ }^{3}$ This survey includes information on how 26,168 randomly selected individuals perform in terms of entrepreneurial engagement levels, ranging from no involvement in entrepreneurial activity to

\footnotetext{
${ }^{3}$ The European Commission initiated these surveys on entrepreneurship in 2000. In that year approximately 8,000 interviews were conducted among citizens in the $15 \mathrm{EU}$ Member States. Similar surveys were performed in 2001, 2002, 2003, 2004, and 2007 with increasing numbers of covered countries, survey questions, and sample sizes.
} 
established business ownership. The dataset covers 36 countries, including the 27 EU Member States, ${ }^{4}$ five non-EU European countries (Croatia, Iceland, Norway, Switzerland, and Turkey), the US, and three Asian countries (China, Japan, and South Korea). Each national sample is representative of the population aged 15 years and above. The national samples consist of approximately 500 or 1,000 observations. ${ }^{5}$ In all countries both rural and urban areas were targeted. An exception is China where the interviews were conducted in 50 cities.

\subsection{Stages of the entrepreneurial process}

For each individual it is known to what extent (s)he is engaged in the entrepreneurial process. This enables us to identify gender differences at several stages in this process. Respondents were asked to provide information on whether they had ever started a business or were taking steps to start one. Each individual was asked to select one of the following five categories ${ }^{6}$ :

(1) No, it never came to your mind ("never considered");

(2) No, but you are thinking about it ("thinking");

(3) Yes, you are currently taking steps to start a new business ("taking steps");

\footnotetext{
"Consisting of the 15 "old" Member States (Austria, Belgium, Denmark, Finland, France, Germany, Greece, Ireland, Italy, Luxembourg, the Netherlands, Portugal, Spain, Sweden, and the United Kingdom) and the 12 "new" Member States (Bulgaria, Cyprus, the Czech Republic, Estonia, Hungary, Latvia, Lithuania, Malta, Poland, Romania, Slovakia, and Slovenia).

${ }^{5}$ In principle, the national samples contain 500 observations. However, this number is 1,000 in some countries, i.e., Belgium, the Czech Republic, France, Germany, Greece, Hungary, Italy, Japan, the Netherlands, Poland, Portugal, South Korea, Spain, the UK, and the US.

6 The questionnaire includes three additional answer categories: (2a) No, you thought of it or had already taken steps to start a business but gave up ("gave up"); (5a) Yes, you once started a business, but you are currently no longer an entrepreneur since the business has failed ("failure"); and (5b) Yes, you once started a business, but you are currently no longer an entrepreneur since the business was sold, transferred or closed ("sell-off"). Individuals who responded that they were at one of these engagement levels are not incorporated in our analysis because this would address a different research question. See Stam et al. (2010) for an analysis that includes these three engagement levels.
}

(4) Yes, you have started or have taken over a business in the last 3 years, and it is still active ("young business");

(5) Yes, you started or took over a business more than 3 years ago, and it is still active ("mature business").

\subsection{Control variables}

Although this paper takes an international perspective on gender differences in entrepreneurship, a number of individual characteristics serve as control variables. That is, men may have an advantage in the entrepreneurial process because they have different characteristics or own different types of ventures than women. Indeed, socioeconomic and perceptual variables have been shown to explain gender differences to a large extent (Arenius and Minniti 2005; Minniti and Nardone 2007; Koellinger et al. 2008).

As relevant socioeconomic control variables we include age, education, and parents' occupation. The importance of these variables has been demonstrated in several stages of the entrepreneurial process (Van der Zwan et al. 2009). In addition, (potential) female and male entrepreneurs may differ regarding their age structure, for example because women's participation in the labor market is affected by child bearing and caring responsibilities (Collins-Dodd et al. 2004). In our dataset, education level is the age at which individuals leave school and varies between 15 and 25 years. Those who have never received full-time education are assigned the lowest possible value of 15. In addition, we take into account the occupational status of the mother and father, distinguishing between self-employment (value 1) and other occupational states (value 0).

In terms of perceptual variables, it has been observed that women are less optimistic than men and are often less confident about their entrepreneurial capabilities (Bengtsson et al. 2005; Verheul et al. 2005; Koellinger et al. 2007; Niederle and Vesterlund 2007). Hence, women's perceptions of the environment may be more realistic (or more closely related to the objective state of the environment) than those of men. It is therefore likely that women and men differ in their interpretation of objectively identical circumstances. This illustrates the importance of taking into account perception variables when analyzing gender 
differences in entrepreneurship. This importance also stems from the fact that entrepreneurial decisionmaking may be influenced more by subjective perceptions than by the objective environment (Krueger and Brazeal 1994; Arenius and Minniti 2005; Koellinger et al. 2007). We take into account three perceptions of the entrepreneurial environment, that is, the perception of financial, administrative, and informational barriers to starting a business. There is some evidence that perceived barriers to entrepreneurship have different effects at different stages of the entrepreneurial process (Kouriloff 2000; Begley et al. 2005; Van der Zwan et al. 2011).

Subjective perceptions of the entrepreneurial environment were captured as follows: "Do you strongly agree, agree, disagree or strongly disagree with the following statements"?

- "It is difficult to start one's own business due to the complex administrative procedures" (perceived administrative complexities);

- "It is difficult to obtain sufficient information on how to start a business" (perceived lack of startup information).

- "It is difficult to start one's own business due to a lack of available financial support" (perceived financial constraints);

We create three perception variables with the value 1 for strong agreement or agreement, and the value 0 for strong disagreement or disagreement. How individuals rate these statements is likely to be influenced by the innate optimistic character of an individual. Therefore, we include self-reported optimism, i.e., an individual's ranking of the statement: "I am optimistic about my future" (with the value 1 assigned in the case of strong agreement or agreement and the value 0 assigned for "strong disagreement" or "disagreement").

We also include a measure of risk tolerance, because women may have a different attitude towards risk than men (Sexton and Bowman-Upton 1990; Johnson and Powell 1994) which may influence their entrepreneurial participation. This measure of risk tolerance is based on the rating of the following statement: "One should not start a business if there is a risk it might fail" where the value 1 is assigned in case of strong disagreement or disagreement and the value 0 in case of strong agreement or agreement.
Metropolitan or urban areas provide entrepreneurial opportunities, resources, and social networks, which stimulate the process of new venture creation. In addition, positive effects of knowledge spillovers on firm birth, growth, and survival in urban areas have been established (Acs and Armington 2004; Audretsch and Dohse 2007; Raspe and Van Oort 2008). However, more intense competition in these areas may also lead to higher probabilities of exit. According to Fairlie and Robb (2009, p. 379): “( ...) firms located in urban areas are more likely to close and are less likely to have employees, but are more likely to have large profits and have higher sales than firms located in non-urban areas". To control for the differential distribution of (potential) female and male entrepreneurs across urban and rural areas, we include a measure of urbanization. That is, each individual indicated whether (s)he was located in a metropolitan or urban area (value 1), or in a rural area (value 0 ).

\subsection{Model}

To investigate gender differences at several stages of the entrepreneurial process across countries, we make use of random-coefficient binary logit models. The two values of the binary variables indicate whether an individual made it beyond a specific engagement level. We perform four random-coefficient binary logit regressions to compare individuals who are beyond an engagement level with persons who are exactly at this level. ${ }^{7}$ These four regressions are associated with the following comparisons. First, individuals at "never considered" (the dependent variable takes the value 0) are compared with individuals at the four remaining engagement levels (the dependent variable takes the value 1) to assess the influence of gender on start-up considerations. Second, individuals at "thinking" (value 0) are compared with individuals who are at any higher engagement level (i.e., "taking steps", "young business", or "mature business"; value 1). This comparison gives insight into the probability of converting start-up considerations into nascent activities. Third, we compare individuals at "taking steps" (value 0)

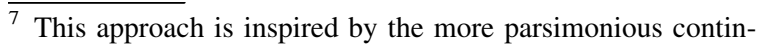
uation ratio logit model (Van der Zwan et al. 2009) which is used in situations where "categories represent stages in some progression” (Rabe-Hesketh and Skrondal (2008, p. 323).
} 
with those who have a business (either "young business" or "mature business"; value 1). Fourth, we can create insight into the likelihood of business survival when analyzing the transition from "young business" (value 0) to "mature business" (value 1).

The random-coefficient binary logit model has country-specific random intercepts and country-specific random gender coefficients. Hence, each country has its own intercept that is a linear function of an "average" intercept and a disturbance term. In the same manner, the gender coefficient is allowed to vary across countries. More precisely, a country's gender coefficient depends on an "average" gender coefficient and a country-specific disturbance term. The disturbance terms measure country-specific effects that are not included in the model. Hence, we control for unobserved heterogeneity across countries. Another advantage of these models is that countries are not treated as separate entities, but their intercepts and gender coefficients are modeled in a second level. In addition, the model is parsimonious in that it refrains from estimating many coefficients, as would be the case in a setting where interaction terms are constructed between the gender variable and country dummies. ${ }^{8}$

In technical terms the random-parameter binary logit model is given by $\operatorname{Pr}\left(Y_{i j k}=1\right)=$ $\operatorname{Pr}\left(Y^{*}{ }_{i j k}>0\right)=\Lambda\left(Y^{*} i j k\right.$, where $Y_{i j k}(k=1, \ldots, 4)$ is a binary (1/0) dependent variable for individual $i$, who lives in country $j(j=1, \ldots, 36)$. The variable $Y_{i j k}$ denotes whether an individual made it beyond a given engagement level (i.e., "never considered", "thinking", "taking steps", "young business") or is exactly at this level. ${ }^{9} Y_{i j k}^{*}$ is an unobservable continuous variable, and $\Lambda$ denotes the cumulative logistic distribution function. We now define $Y^{*}{ }_{i j k}=\alpha_{j k}+$ $\beta_{0 j k} x_{0 i j}+\cdots+\beta_{p k} x_{p i j}+\varepsilon_{i j k}$ with $\alpha_{j k}=\gamma_{o k}+u_{j k}$ and $\beta_{0 j k}=\delta_{O k}+v_{j k}$ where variable $x_{O i j}$ denotes gender and variables $x_{1 i j}, \ldots, x_{p i j}$ denote the control variables. Furthermore, $\varepsilon_{i j k}$ has a logistic distribution with zero

\footnotetext{
${ }^{8}$ Estimation of these random-intercept binary logit models is performed using adaptive Gaussian quadrature with seven integration points in Stata 11.0. More integration points do not lead to more accurate estimates. In these random-coefficient models, no country dummies are included; a country-specific random-intercept is included instead. Thus, the intercept is also allowed to vary across countries.

9 Note that for individuals at "never considered", $Y_{i j k}$ is only identified for $k=1$. For individuals who are at "mature business", $Y_{i j k}$ is identified for $k=1, \ldots, 4$.
}

mean and variance $\pi^{2} / 3$ and $u_{j k}$ and $v_{j k}$ are normally distributed error terms with zero means and variances $\phi_{k}^{2}$ and $\theta_{k}^{2}$, respectively; $\varepsilon_{i j k}$ and $u_{j k}$ have correlation 0 , as do $\varepsilon_{i j k}$ and $v_{j k}$. Moreover, $u_{j k}$ and $v_{j k}$ are allowed to be correlated (with covariance $\sigma_{k}$ ).

One can rewrite the random-parameter binary logit model as a ratio of probabilities, i.e., $\operatorname{Pr}\left(Y_{i j k}=1\right)$ / $\operatorname{Pr}\left(Y_{i j k}=0\right)=\exp \left(\alpha_{j k}+\beta_{0 j k} x_{0 i j}+\ldots+\beta_{p k} x_{p i j}\right)$.

This enables interpretation of the acquired results, which is particularly important in this study where country-specific marginal effects for gender cannot be calculated because of the random part $v_{j k}$. The odds ratios can be computed by exponentiating the coefficient of interest, e.g. $\exp \left(\beta_{0 j k}\right)$ for some $j$ and $k$. Odds ratios inform us about the factor by which the odds of being beyond a certain engagement level are expected to change given a one-unit change in a variable. This one-unit change may refer to the comparison between women and men, or a one-year age difference. Suppose, for example, that the coefficient of gender for Belgian in the first regression $(k=1)$ equals 1 . Then, Belgian men would be, for example, $\exp (1)=2.718$ times more likely to be beyond "never considered" than Belgian women. The value 2.718 is referred to as the odds ratio. An odds ratio of 1 (equivalent to a coefficient of 0 ) would imply equal chances of advancement for women and men in the entrepreneurial process.

\section{Results}

Table 1 shows the distribution of women and men across the five engagement levels for each country. Although Table 1 does not provide information on the chances of advancement for women and men, it gives an impression of the differences between countries regarding the backward position of women in the entrepreneurial process. To clarify the numbers in Table 1, we concentrate on Belgium as an example. First, we note that many Belgians have never considered setting up a business: $92 \%$ of all women and $86 \%$ all men belong to this category. However, the difference between Belgian women and men at the level of "never considered" is relatively small compared with, for example, Finland, Norway, and Estonia. The forward position of Belgian women in the entrepreneurial process can also be observed at the more advanced stages of the entrepreneurial process. 
Table 1 Distribution of women (W) and men (M) across the engagement levels

\begin{tabular}{|c|c|c|c|c|c|c|c|c|c|c|}
\hline & \multicolumn{2}{|c|}{ "Never considered" } & \multicolumn{2}{|c|}{ "Thinking" } & \multicolumn{2}{|c|}{ “Taking steps" } & \multicolumn{2}{|c|}{ "Young business" } & \multicolumn{2}{|c|}{ "Mature business" } \\
\hline & $\mathrm{W}$ & M & $\mathrm{W}$ & M & W & M & $\mathrm{W}$ & M & W & M \\
\hline Austria & 0.82 & 0.64 & 0.08 & 0.11 & 0.02 & 0.06 & 0.04 & 0.01 & 0.04 & 0.18 \\
\hline Belgium & 0.92 & 0.86 & 0.04 & 0.05 & 0.01 & 0.02 & 0.01 & 0.05 & 0.02 & 0.03 \\
\hline Bulgaria & 0.66 & 0.52 & 0.20 & 0.22 & 0.02 & 0.03 & 0.03 & 0.05 & 0.10 & 0.19 \\
\hline China & 0.43 & 0.26 & 0.22 & 0.23 & 0.24 & 0.31 & 0.06 & 0.10 & 0.05 & 0.10 \\
\hline Croatia & 0.82 & 0.72 & 0.09 & 0.09 & 0.04 & 0.07 & 0.01 & 0.04 & 0.03 & 0.08 \\
\hline Cyprus & 0.74 & 0.54 & 0.09 & 0.10 & 0.05 & 0.11 & 0.07 & 0.09 & 0.06 & 0.17 \\
\hline Czech Republic & 0.74 & 0.60 & 0.12 & 0.12 & 0.03 & 0.05 & 0.03 & 0.03 & 0.08 & 0.20 \\
\hline Denmark & 0.70 & 0.54 & 0.25 & 0.24 & 0.01 & 0.03 & 0.02 & 0.06 & 0.02 & 0.13 \\
\hline Estonia & 0.75 & 0.48 & 0.12 & 0.13 & 0.04 & 0.16 & 0.04 & 0.05 & 0.06 & 0.19 \\
\hline Finland & 0.78 & 0.51 & 0.03 & 0.05 & 0.06 & 0.08 & 0.06 & 0.08 & 0.07 & 0.27 \\
\hline France & 0.78 & 0.67 & 0.12 & 0.20 & 0.03 & 0.04 & 0.02 & 0.04 & 0.04 & 0.06 \\
\hline Germany & 0.79 & 0.59 & 0.08 & 0.14 & 0.04 & 0.08 & 0.02 & 0.05 & 0.07 & 0.15 \\
\hline Greece & 0.59 & 0.42 & 0.21 & 0.26 & 0.03 & 0.06 & 0.04 & 0.09 & 0.12 & 0.17 \\
\hline Hungary & 0.75 & 0.56 & 0.12 & 0.20 & 0.02 & 0.03 & 0.03 & 0.04 & 0.09 & 0.18 \\
\hline Iceland & 0.55 & 0.37 & 0.19 & 0.20 & 0.07 & 0.07 & 0.06 & 0.10 & 0.13 & 0.25 \\
\hline Ireland & 0.71 & 0.56 & 0.15 & 0.17 & 0.04 & 0.10 & 0.04 & 0.05 & 0.05 & 0.12 \\
\hline Italy & 0.82 & 0.59 & 0.06 & 0.08 & 0.04 & 0.08 & 0.02 & 0.08 & 0.05 & 0.17 \\
\hline Japan & 0.87 & 0.70 & 0.05 & 0.06 & 0.01 & 0.03 & 0.01 & 0.05 & 0.06 & 0.17 \\
\hline Latvia & 0.68 & 0.49 & 0.22 & 0.31 & 0.02 & 0.04 & 0.02 & 0.03 & 0.05 & 0.13 \\
\hline Lithuania & 0.77 & 0.58 & 0.11 & 0.15 & 0.05 & 0.10 & 0.02 & 0.07 & 0.06 & 0.10 \\
\hline Luxembourg & 0.85 & 0.79 & 0.08 & 0.09 & 0.03 & 0.04 & 0.01 & 0.04 & 0.03 & 0.05 \\
\hline Malta & 0.88 & 0.79 & 0.07 & 0.12 & 0.01 & 0.03 & 0.01 & 0.03 & 0.02 & 0.04 \\
\hline Netherlands & 0.76 & 0.67 & 0.07 & 0.09 & 0.05 & 0.05 & 0.05 & 0.05 & 0.07 & 0.14 \\
\hline Norway & 0.80 & 0.50 & 0.08 & 0.14 & 0.04 & 0.06 & 0.02 & 0.08 & 0.06 & 0.23 \\
\hline Poland & 0.69 & 0.46 & 0.15 & 0.20 & 0.06 & 0.09 & 0.04 & 0.06 & 0.06 & 0.19 \\
\hline Portugal & 0.85 & 0.67 & 0.03 & 0.06 & 0.03 & 0.03 & 0.03 & 0.06 & 0.05 & 0.19 \\
\hline Romania & 0.71 & 0.49 & 0.16 & 0.23 & 0.05 & 0.14 & 0.03 & 0.09 & 0.05 & 0.05 \\
\hline Slovakia & 0.82 & 0.60 & 0.12 & 0.20 & 0.01 & 0.07 & 0.03 & 0.05 & 0.02 & 0.08 \\
\hline Slovenia & 0.83 & 0.66 & 0.10 & 0.17 & 0.03 & 0.07 & 0.01 & 0.00 & 0.03 & 0.10 \\
\hline South Korea & 0.63 & 0.53 & 0.16 & 0.21 & 0.07 & 0.07 & 0.06 & 0.03 & 0.09 & 0.16 \\
\hline Spain & 0.83 & 0.64 & 0.07 & 0.14 & 0.01 & 0.05 & 0.02 & 0.06 & 0.06 & 0.11 \\
\hline Sweden & 0.66 & 0.50 & 0.19 & 0.24 & 0.07 & 0.11 & 0.04 & 0.06 & 0.04 & 0.11 \\
\hline Switzerland & 0.71 & 0.57 & 0.17 & 0.21 & 0.03 & 0.03 & 0.02 & 0.04 & 0.07 & 0.14 \\
\hline Turkey & 0.67 & 0.43 & 0.16 & 0.23 & 0.12 & 0.13 & 0.01 & 0.10 & 0.03 & 0.11 \\
\hline United Kingdom & 0.80 & 0.69 & 0.09 & 0.09 & 0.03 & 0.05 & 0.02 & 0.04 & 0.06 & 0.13 \\
\hline United States & 0.61 & 0.38 & 0.15 & 0.17 & 0.10 & 0.19 & 0.04 & 0.08 & 0.11 & 0.19 \\
\hline
\end{tabular}

Frequencies are based on 24,776 observations. Note that the questionnaire contains three other engagement levels (see footnote 6). Hence, the percentages in this table are based on a sample that includes only individuals who are in "never considered", "thinking", "taking steps", "young business", or "mature business"

As reported in Table 2, Spearman correlations between all dummy variables with values 1 and 0 (including gender) are low. With the exception of the
Spearman correlation between self-employed mother and self-employed father (which is 0.45 ) all other values do not exceed 0.33 in absolute values. In 
Table 2 Correlations between control variables

\begin{tabular}{|c|c|c|c|c|c|c|c|c|c|c|c|}
\hline & & (1) & (2) & (3) & (4) & (5) & (6) & (7) & (8) & (9) & (10) \\
\hline (1) & Male & & & & & & & & & & \\
\hline (2) & Age & -0.04 & & & & & & & & & \\
\hline (3) & Education & 0.08 & -0.11 & & & & & & & & \\
\hline (4) & Self-employed father & 0.02 & 0.02 & -0.01 & & & & & & & \\
\hline (5) & Self-employed mother & 0.01 & -0.01 & -0.02 & 0.45 & & & & & & \\
\hline (6) & Risk tolerance & 0.07 & -0.13 & 0.16 & 0.02 & 0.02 & & & & & \\
\hline (7) & Optimism & 0.03 & -0.06 & 0.09 & 0.02 & 0.01 & 0.06 & & & & \\
\hline (8) & Perception adm. compl. & -0.05 & 0.07 & -0.07 & -0.02 & -0.04 & -0.15 & -0.05 & & & \\
\hline (9) & Perception insuff. info & -0.06 & 0.03 & -0.13 & 0.01 & 0.02 & -0.17 & -0.07 & 0.33 & & \\
\hline (10) & Perception financial constr. & -0.06 & 0.02 & -0.06 & -0.03 & -0.04 & -0.12 & -0.05 & 0.27 & 0.21 & \\
\hline (11) & Urban versus rural & -0.02 & -0.04 & 0.14 & -0.02 & -0.04 & 0.03 & -0.01 & -0.04 & 0.00 & -0.02 \\
\hline
\end{tabular}

Spearman correlations are used for pairs of dummy variables (with values 0 and 1), whereas Pearson correlations are used for all other pairs of variables. The correlations are based on 18,791 observations

addition, Pearson correlations between the continuous variables age and education with all dummy variables are consistently lower than 0.17 in absolute values. Hence, we do not expect any problems of multicollinearity in the regression analyses that follow.

The estimation results of the random-coefficient binary logit models are shown in Table 3 . The four columns of results represent the four possible transitions on the entrepreneurial ladder $(k=1, \cdots, 4)$. Our focus is on gender differences in entrepreneurial involvement across countries at four specific transitions on the entrepreneurial ladder. The estimates of $\theta_{k}^{2}$ (for $k=1, \cdots, 4$ ) and their statistical significances provide information about the amount of crosscountry variation in the gender coefficient. Table 3 shows that cross-country variation is greatest for the earliest transition from "never considered" to "thinking" (value of $0.021 ; p$ value $<0.01$ ) and the final transition from "young business" to "mature business" (value is $0.052 ; p$ value $>0.10$ ) in the entrepreneurial process. ${ }^{10}$ Cross-country variation is negligible for the third transition from "taking steps" to "young business". 11

\footnotetext{
$\overline{10}$ The values of $\phi_{k}^{2}, \theta_{k}^{2}$, and $\sigma_{k}$ are invariant to data scaling (Rabe-Hesketh and Skrondal, 2008).

11 A test on the joint significance of $\phi_{k}^{2}, \theta_{k}^{2}$, and $\sigma_{k}$ is rejected at the $1 \%$ level for the first three regressions. Hence, the randomparameter specification (including random-intercept) is preferred to a simple logit model for these three cases.
}

Table 3 also shows the values of $\delta_{O k}$ and $v_{j k}{ }^{12}$ Values of $v_{j k}$ indicate the deviation of a country's gender coefficient from the "average" gender coefficient $\delta_{O k}$. It seems that men mainly have an advantage over women with regard to the first two transitions in the entrepreneurial process (i.e., from "never considered" to "thinking" and from "thinking" to "taking steps"). This can be seen from the "average" gender coefficient in the first column of Table $3(0.767 ; p$ value $<0.01)$, which is in sharp contrast with the "average" gender coefficients in the other columns: $0.390 \quad(p$ value $<0.01), \quad 0.191$ ( $p$ value $<0.05$ ), and 0.221 ( $p$ value $<0.05)$, respectively. Hence, on average, men are more than twice $(\exp (0.767)=2.153)$ as likely as women to think about engaging in entrepreneurship. Given that women and men think about entrepreneurship as a career option, men are, on average, almost 1.5 times as likely as women to undertake nascent activities $(\exp (0.390)=1.477)$. The odds ratios corresponding to the last two transitions (from "taking steps" to "young business" and from "young business" to "mature business") are considerably lower, i.e., 1.209 and 1.247 , respectively.

The country-specific gender coefficients for the first transition ("never considered" to "thinking")

\footnotetext{
$\overline{12}$ However, we do not provide standard errors for $v_{j k}$ because the distribution of the predicted values of $v_{j k}$ is not known when the model is true; hence, the predicted values of $v_{j k}$ should only be used to rank countries (Rabe-Hesketh and Skrondal 2008, p. 264).
} 
Table 3 Estimation results random-parameter binary logit regressions

\begin{tabular}{|c|c|c|c|c|c|c|c|c|}
\hline & \multicolumn{2}{|c|}{$\begin{array}{l}\text { Model } 1 \text { ("never } \\
\text { considered" versus } \\
\text { above) }\end{array}$} & \multicolumn{2}{|c|}{$\begin{array}{l}\text { Model } 2 \text { ("thinking" } \\
\text { versus above) }\end{array}$} & \multicolumn{2}{|c|}{$\begin{array}{l}\text { Model } 3 \text { ("taking steps" } \\
\text { versus above) }\end{array}$} & \multicolumn{2}{|c|}{$\begin{array}{l}\text { Model } 4 \text { ("young" } \\
\text { versus "mature } \\
\text { business") }\end{array}$} \\
\hline & Coeff. & Std.err. & Coeff. & Std.err. & Coeff. & Std.err. & Coeff. & Std.err. \\
\hline \multicolumn{9}{|l|}{ Individual characteristics } \\
\hline Age & $-0.032 * *$ & 0.001 & $0.040 * *$ & 0.003 & $0.053 * *$ & 0.004 & $0.052 * *$ & 0.004 \\
\hline Education & $0.070 * *$ & 0.006 & $0.040 * *$ & 0.011 & -0.010 & 0.014 & $-0.035^{*}$ & 0.016 \\
\hline Self-employed father & $0.406 * *$ & 0.053 & $0.221 * *$ & 0.082 & $0.411 * *$ & 0.112 & -0.087 & 0.120 \\
\hline Self-employed mother & $0.318 * *$ & 0.070 & $0.477 * *$ & 0.109 & -0.082 & 0.139 & $0.423 * *$ & 0.155 \\
\hline Risk tolerance & $0.499 * *$ & 0.043 & $0.160^{*}$ & 0.070 & $0.205^{*}$ & 0.098 & 0.063 & 0.107 \\
\hline Optimism & $0.220 * *$ & 0.052 & $0.296^{* *}$ & 0.087 & -0.152 & 0.130 & -0.159 & 0.140 \\
\hline Perception adm. compl. & $-0.306^{* *}$ & 0.050 & $-0.362 * *$ & 0.078 & $-0.382 * *$ & 0.107 & -0.119 & 0.116 \\
\hline Perception insuff. info & $-0.133 * *$ & 0.045 & -0.009 & 0.072 & -0.044 & 0.100 & 0.060 & 0.111 \\
\hline Perception financial constr. & -0.044 & 0.058 & -0.048 & 0.091 & 0.052 & 0.120 & 0.109 & 0.131 \\
\hline Urban versus rural & -0.031 & 0.045 & -0.132 & 0.074 & -0.191 & 0.101 & $-0.288 *$ & 0.111 \\
\hline \multicolumn{9}{|c|}{ "Average" gender coefficient $\left(\delta_{O k}\right)$} \\
\hline Male & $0.767 * *$ & 0.048 & $0.390 * *$ & 0.069 & $0.191 *$ & 0.095 & $0.221 *$ & 0.110 \\
\hline \multicolumn{9}{|c|}{ Country deviations from "average" gender coefficient ( $v_{j k}$ for all $j$ ) } \\
\hline Austria & 0.001 & & -0.019 & & -0.003 & & 0.169 & \\
\hline Belgium & -0.137 & & 0.017 & & 0.001 & & -0.376 & \\
\hline Bulgaria & 0.013 & & 0.063 & & -0.011 & & 0.172 & \\
\hline China & 0.065 & & -0.060 & & 0.014 & & -0.272 & \\
\hline Croatia & -0.090 & & -0.001 & & 0.003 & & -0.037 & \\
\hline Cyprus & 0.046 & & -0.081 & & 0.001 & & -0.107 & \\
\hline Czech Republic & -0.134 & & -0.047 & & -0.005 & & 0.354 & \\
\hline Denmark & 0.052 & & 0.163 & & -0.007 & & -0.055 & \\
\hline Estonia & 0.081 & & -0.010 & & 0.005 & & 0.087 & \\
\hline Finland & 0.125 & & -0.125 & & -0.003 & & 0.090 & \\
\hline France & -0.056 & & 0.042 & & 0.001 & & -0.103 & \\
\hline Germany & 0.018 & & -0.016 & & 0.002 & & 0.044 & \\
\hline Greece & 0.067 & & 0.021 & & -0.008 & & 0.003 & \\
\hline Hungary & 0.026 & & -0.027 & & -0.009 & & 0.157 & \\
\hline Iceland & 0.080 & & -0.008 & & -0.003 & & -0.055 & \\
\hline Ireland & -0.001 & & 0.048 & & 0.006 & & 0.048 & \\
\hline Italy & 0.130 & & -0.095 & & -0.001 & & -0.068 & \\
\hline Japan & 0.033 & & -0.008 & & -0.003 & & 0.015 & \\
\hline Latvia & 0.079 & & 0.080 & & -0.004 & & 0.118 & \\
\hline Lithuania & 0.000 & & -0.019 & & -0.003 & & 0.035 & \\
\hline Luxembourg & -0.161 & & 0.029 & & 0.002 & & -0.124 & \\
\hline Malta & -0.075 & & 0.026 & & 0.003 & & -0.019 & \\
\hline Netherlands & -0.154 & & -0.041 & & 0.002 & & -0.026 & \\
\hline Norway & 0.049 & & -0.024 & & -0.003 & & 0.092 & \\
\hline Poland & 0.047 & & 0.024 & & 0.000 & & 0.128 & \\
\hline Portugal & -0.043 & & -0.120 & & -0.006 & & 0.117 & \\
\hline Romania & 0.011 & & 0.055 & & 0.003 & & -0.207 & \\
\hline Slovakia & 0.051 & & 0.078 & & 0.003 & & -0.121 & \\
\hline
\end{tabular}


Table 3 continued

\begin{tabular}{|c|c|c|c|c|c|c|c|c|}
\hline & \multicolumn{2}{|c|}{$\begin{array}{l}\text { Model } 1 \text { ("never } \\
\text { considered" versus } \\
\text { above) }\end{array}$} & \multicolumn{2}{|c|}{$\begin{array}{l}\text { Model } 2 \text { ("thinking" } \\
\text { versus above) }\end{array}$} & \multicolumn{2}{|c|}{$\begin{array}{l}\text { Model } 3 \text { ("taking steps" } \\
\text { versus above) }\end{array}$} & \multicolumn{2}{|c|}{$\begin{array}{l}\text { Model } 4 \text { ("young" } \\
\text { versus "mature } \\
\text { business") }\end{array}$} \\
\hline & Coeff. & Std.err. & Coeff. & Std.err. & Coeff. & Std.err. & Coeff. & Std.err. \\
\hline Slovenia & -0.016 & & 0.057 & & 0.007 & & 0.124 & \\
\hline South Korea & -0.142 & & 0.009 & & 0.002 & & 0.044 & \\
\hline Spain & 0.029 & & -0.038 & & -0.007 & & -0.005 & \\
\hline Sweden & 0.010 & & 0.025 & & 0.005 & & -0.195 & \\
\hline Switzerland & -0.048 & & 0.076 & & 0.002 & & -0.062 & \\
\hline Turkey & 0.098 & & -0.053 & & 0.004 & & -0.096 & \\
\hline United Kingdom & -0.107 & & -0.006 & & 0.002 & & 0.091 & \\
\hline United States & 0.040 & & -0.002 & & 0.011 & & -0.050 & \\
\hline Number of observations & 13,137 & & 4,673 & & 2,966 & & 2,109 & \\
\hline Log likelihood & $-7,296$ & & $-2,800$ & & $-1,554$ & & $-1,198$ & \\
\hline$\phi_{k}^{2}$ & $0.189 * *$ & & $0.285^{* *}$ & & $0.250 * *$ & & 0.007 & \\
\hline$\theta_{k}^{2}$ & $0.021 * *$ & & 0.008 & & 0.000 & & 0.052 & \\
\hline$\sigma_{k}$ & 0.012 & & -0.036 & & -0.003 & & 0.019 & \\
\hline
\end{tabular}

Estimates of $\gamma_{o k}$ are not reported

** Denotes significance at $1 \%$; $*$ at $5 \%$

range from $0.767-0.161=0.605$ for Luxembourg to $0.767+0.130=0.897$ for Italy. The gender gap is smallest in Luxembourg, Netherlands, and South Korea, and largest in Italy, Finland, and Turkey. Although no information is provided on the significance of the joint gender coefficients $\beta_{0 j k}$ for each $j$ and $k$, we are tempted to conclude that all country gender coefficients significantly differ from zero in this first regression.

The range of the gender coefficients in the second column is as wide as that in the first column. The coefficients range from $0.390-0.125=0.264$ for Finland to $0.390+0.163=0.553$ for Denmark. Interestingly, whereas Italy, Finland, and Turkey have the largest gender coefficients for the first transition ("never considered" to "thinking"), the coefficients for these countries are among the six smallest coefficients for the second transition ("thinking" to "taking steps"). Furthermore, Croatia, the Czech Republic, the Netherlands, Portugal, and the United Kingdom are the only countries that have below-average gender coefficients in the first two transitions. In contrast, there are eight countries that have above-average gender coefficients for both transitions. Interestingly, they are either (former) transition countries (Bulgaria, Latvia, Poland,
Romania, and Slovakia) or Scandinavian countries (Denmark and Sweden). Greece also belongs to this group of countries.

The variation across countries regarding the third transition ("taking steps" to "young business") is small. Specifically, the country-specific gender coefficients $\beta_{0 j k}$ range from 0.180 for Bulgaria to 0.205 for China. Many below-average gender coefficients seem to be at the borderline of significance at the $5 \%$ level given the $p$ value of 0.044 that belongs to the "average" gender coefficient. This is also true for the last transition ("young business" to "mature business") where the gender coefficients range from $0.221-0.376=-0.156$ for Belgium to $0.221+$ $0.354=0.575$ for the Czech Republic.

To discover a pattern in the variation of the gender coefficients across all countries (not reported here), we investigate whether the level of economic development, measured in terms of Gross National Income (GNI) per capita, ${ }^{13}$ affects this variation for each

\footnotetext{
${ }_{13}$ Data source: World Development Indicators 2009, World Bank. GNI values are converted to current international dollars using purchasing power parity rates (PPP). For Malta (2007), Cyprus, and Switzerland (2008) data from previous years are used.
} 
Table 4 Estimation results random-parameter binary logit regressions including country classification

\begin{tabular}{|c|c|c|c|c|c|c|c|c|}
\hline & \multicolumn{2}{|c|}{$\begin{array}{l}\text { Model } 1 \text { ("never } \\
\text { considered" versus above) }\end{array}$} & \multicolumn{2}{|c|}{$\begin{array}{l}\text { Model } 2 \text { ("thinking" } \\
\text { versus above) }\end{array}$} & \multicolumn{2}{|c|}{$\begin{array}{l}\text { Model } 3 \text { ("taking steps" } \\
\text { versus above) }\end{array}$} & \multicolumn{2}{|c|}{$\begin{array}{l}\text { Model } 4 \text { ("young" versus } \\
\text { "mature business") }\end{array}$} \\
\hline & Coeff. & Std.err. & Coeff. & Std.err. & Coeff. & Std.err. & Coeff. & Std.err. \\
\hline \multicolumn{9}{|c|}{ "Average" gender coefficient $\left(\delta_{O k}\right)$} \\
\hline Male & $0.762 * *$ & 0.047 & $0.409 * *$ & 0.069 & 0.202 & 0.107 & 0.199 & 0.141 \\
\hline \multicolumn{9}{|c|}{ Deviations from "average" gender coefficient ( $v_{j k}$ for all $j$ ) } \\
\hline Europe non-transition & 0.001 & & -0.005 & & 0.013 & & -0.036 & \\
\hline Europe transition & -0.000 & & 0.040 & & -0.018 & & 0.238 & \\
\hline Japan and South Korea & 0.001 & & 0.036 & & -0.012 & & 0.042 & \\
\hline China & -0.001 & & -0.064 & & 0.025 & & -0.218 & \\
\hline US & -0.001 & & -0.006 & & 0.017 & & -0.034 & \\
\hline Number of observations & 13,137 & & 4,673 & & 2,966 & & 2,109 & \\
\hline Log likelihood & $-7,421$ & & $-2,859$ & & $-1,567$ & & $-1,198$ & \\
\hline$\phi_{k}^{2}$ & $0.153 * *$ & & $0.045^{* *}$ & & $0.353 * *$ & & 0.004 & \\
\hline$\theta_{k}^{2}$ & 0.000 & & 0.002 & & 0.001 & & 0.035 & \\
\hline$\sigma_{k}$ & -0.000 & & -0.009 & & -0.011 & & -0.011 & \\
\hline
\end{tabular}

Estimates of $\gamma_{0 k}$ and coefficients of control variables are not reported

** Denotes significance at $1 \%$; $*$ at $5 \%$

position in the entrepreneurial process. ${ }^{14}$ It seems that per capita income has a strong significant negative effect on gender differences for the first transition ( $p$ value $=0.020$ ), but that this effect is absent for other transitions ( $p$ values are $0.787,0.981,0.633$ ). Thus, low-income countries seem to be characterized by large gender differences regarding this first transition from "never considered" to "thinking". This is in contrast with our expectation that, in particular in low-income countries, the level of female entrepreneurial activity would be more similar to that of male entrepreneurial activity. Adding a quadratic term of per capita income does not lead to improved explanatory power.

In another exercise to summarize our results on gender differences in entrepreneurial activity across countries, we divide all European countries into transition and non-transition economies. The following 11 countries can be regarded as transition countries in our sample: Bulgaria, Croatia, the Czech Republic, Estonia, Hungary, Latvia, Lithuania, Poland, Romania, Slovakia, and Slovenia. In addition, the Asian countries are divided into the former communist country of China on one side and Japan and South Korea on the other. Hence, our

\footnotetext{
$\overline{14}$ This is done by adding GNI per capita to $\beta_{O j k}=\delta_{O k}+v_{j k}$.
}

classification consists of five groups of countries: European non-transition countries, European transition countries, Asian non-transition countries, an Asian transition country (China), and the US. Again, we perform four random-parameter binary logit regressions. Table 4 displays the "average" gender coefficients $\delta_{O k}$ and the deviations $v_{j k}$ of these five groups from $\delta_{0 k}{ }^{15}$ No pattern can be observed for the first transition. The results for the transition from "thinking" to "taking steps" reveal that the gender gap is greatest in European transition countries and smallest in China. This pattern for the transition countries is also visible for the final transition from "young business" to "mature business". For the third transition from "taking steps" to "young business" the findings are reversed.

The results for the control variables in Table 3 do not lead to surprising conclusions. Both socioeconomic characteristics (age, education, and parents' occupation) and perceived environmental barriers (in terms of perceived administrative complexities) seem to be important for explaining advancement in the entrepreneurial process. Note that self-employed parents may also contribute to the success of the

$\overline{15}$ A test on the joint significance of $\phi_{k}^{2}, \theta_{k}^{2}$, and $\sigma_{k}$ is rejected at the $5 \%$ level for the first three regressions. 
entrepreneurial venture by providing financial and/or mental support. This can be deduced from our results: having a self-employed father has a significant positive influence on moving from "taking steps" to any higher engagement level, whereas having a self-employed mother is relevant to transforming a young business into a mature one. Degrees of risktaking and optimism have significant influences especially in the early stages of the entrepreneurial process. Finally, the competition element of urbanization seems to prevail over the agglomeration effect given the significant negative coefficient at $1 \%$ in the last transition.

\section{Conclusion}

This paper begins with the claim that regions benefit in terms of competitiveness when a diverse group of people is prepared and able to engage in the entrepreneurial process, i.e., to commence and develop entrepreneurial activities. The focus of the paper is on the importance of the environment in explaining the backward position of women in different stages of the entrepreneurial process. A recent, unique, and representative dataset (Flash Eurobarometer Survey on Entrepreneurship No. 283 by the European Commission) that covers 36 countries is used to investigate international gender differences. The entrepreneurial progress is captured in terms of the entrepreneurial ladder with five positions ("never considered", "thinking", "taking steps", "young business", and "mature business").

We find that, on average, men are twice as likely to consider an entrepreneurial career as women. Whereas men are almost one and a half times as likely to undertake nascent activities ("thinking" to "taking steps") to start a business as women, differences across genders tend to disappear at later stages of the entrepreneurial process ("taking steps" to "young business" and "young business" to "mature business"). Furthermore, considerable cross-country variation exists in the earliest ("never considered" to "thinking") and latest ("young business" to "mature business") transitions. In particular, some European transition economies are characterized by relatively low propensities of women to convert start-up considerations into start-up activities, and by relatively low survival rates of women's entrepreneurial activities. In China, these relationships are reversed, but this may be explained in part by the fact that the Chinese sample is representative of the urban population and not the total population. In addition, GNI per capita has a significant negative relationship with the cross-country gender gap in terms of entrepreneurial intentions ("never considered" to "thinking"). This is an unexpected result compared with other studies (Baughn et al. 2006; Minniti et al. 2006), but our sample is different in that it comprises only high-income countries.

When fostering entrepreneurial activity, governments should be aware of the importance of women because they are a valuable and untapped source of entrepreneurial diversity. In addition, they can function as role models for other females to engage in entrepreneurship. Especially in some European transition countries females seem to face barriers to taking steps to start a business ("thinking" to "taking steps"). These countries also seem to have unfavorable environments for females to keep their businesses in existence ("young business" to "mature business").

By sampling all individuals rather than firms or specific groups of individuals, our dataset includes both informal and formal businesses. This is an advantage because women tend to be overrepresented in informal businesses compared with men (Minniti 2010). Another merit of our dataset is that all types of entrepreneurial activity are captured, including parttime self-employment. This is important because women in part-time entrepreneurship can combine their home and other work commitments and therefore have greater participation in this type of entrepreneurship (Klapper and Parker 2010). However, a limitation of the dataset is the set of control variables. Clearly, variables such as marital status and the number of children have been shown to be important in explaining the entrepreneurial engagement of women (Edwards and Field-Hendrey 2002; Parker 2009, Ch. 4). In addition, household income and partner's work status are important in developing and sustaining the venture. For example, Caputo and Dolinsky (1998) find that the self-employment status of the husband exerts an important influence on the decision of women to enter self-employment. Also, sector decomposition is not available even though this is especially important for the more advanced stages in the entrepreneurial process, because women 
tend to be more concentrated in small scale and lowgrowth sectors (Klapper and Parker 2010).

This paper has established gender differences in entrepreneurial activity from an international perspective. We have related these country differences to the level of economic development. However, a more thorough examination of the international gender gap would be an interesting topic for further research: country-specific factors such as composition of economic activity, labor law, social security systems (child-care facilities), and taxation (tax treatment of double income) may explain the entrepreneurial gender imbalance across countries and may provide valuable policy guidance. Clearly, more research is needed to determine the effects of these countryspecific factors on the position of target groups at the consecutive stages on the entrepreneurial ladder.

Acknowledgments We would like to thank Dr Jaime Silva and Dr Isabel Grilo of the European Commission and Agnes Illyes of Gallup Hungary for providing and explaining the data. The views expressed here are those of the authors and should not be attributed to the European Commission. This paper has been written in cooperation with the research program SCALES, which is carried out by EIM and financed by the Dutch Ministry of Economic Affairs.

Open Access This article is distributed under the terms of the Creative Commons Attribution Noncommercial License which permits any noncommercial use, distribution, and reproduction in any medium, provided the original author(s) and source are credited.

\section{References}

Acs, Z. J., \& Armington, C. (2004). The impact of geographic differences in human capital on service formation rates. Journal of Urban Economics, 56, 244-278.

Ahl, H. J. (2002). The making of the female entrepreneur. A discourse analysis of research texts on women's entrepreneurship. JIBS dissertation series 015, Jönköping University, Sweden.

Aidis, R., Welter, F., Smallbone, D., \& Isakova, N. (2007). Female entrepreneurship in transition economies: The case of Lithuania and Ukraine. Feminist Economics, 13(2), 157-183.

Ajzen, I. (1991). The theory of planned behavior. Organizational Behavior and Human Decision Processes, 50(2), 179-211.

Allen, I. E., Elam, A., Langowitz, N., \& Dean, M. (2008). Global Entrepreneurship Monitor. 2007 Report on Women and Entrepreneurship. Babson College: The Center for Women's Leadership.
Arenius, P., \& Minniti, M. (2005). Perceptual variables and nascent entrepreneurship. Small Business Economics Journal, 24(3), 233-247.

Audretsch, D. B., \& Dohse, D. (2007). Location: A neglected determinant of firm growth. Review of World Economics, 143(1), 79-107.

Audretsch, D. B., Bönte, W., \& Keilbach, M. (2008). Entrepreneurship capital and its impact on knowledge diffusion and economic performance. Journal of Business Venturing, 23(6), 687-698.

Baughn, C. C., Chua, B.-L., \& Neupert, K. E. (2006). The normative context for women's participation in entrepreneurship: a multicountry study. Entrepreneurship Theory and Practice, 30(5), 687-708.

Begley, T. M., Tan, W.-L., \& Schoch, H. (2005). Politicoeconomic factors associated with interest in starting a business: A multi-country study. Entrepreneurship Theory and Practice, 29(1), 35-55.

Bengtsson, C., Persson, M., \& Willenhag, P. (2005). Gender and overconfidence. Economics Letters, LXXXVI, 199-203.

Blanchflower, D. G., Oswald, A., \& Stutzer, A. (2001). Latent entrepreneurship across nations. European Economic Review, 45(4-6), 680-691.

Boden, R. J., \& Nucci, A. R. (2000). On the survival prospects of men's and women's new business ventures. Journal of Business Venturing, 15(4), 347-362.

Broda, C., \& Weinstein, D. E. (2006). Globalization and the gains from variety. Quarterly Journal of Economics, 121(2), 541-585.

Caputo, R. K., \& Dolinsky, A. (1998). Women's choice to pursue self-employment: The role of financial and human capital of household members. Journal of Small Business Management, 36(3), 8-17.

Carree, M. A., \& Thurik, A. R. (2010). The impact of entrepreneurship on economic growth. In D. B. Audretsch \& Z. J. Acs (Eds.), Handbook of entrepreneurship research (pp. 557-594). Berlin: Springer Verlag.

Carter, N. M., Williams, M., \& Reynolds, P. D. (1997). Discontinuance among new firms in retail: The influence of initial resources, strategy, and gender. Journal of Business Venturing, 12(2), 125-145.

Chow, K. W., \& Fung, K. Y. (1996). Firm dynamics and industrialization in the Chinese economy in transition: Implications for small business policy. Journal of Business Venturing, 11(6), 489-505.

Collins-Dodd, C., Gordon, I. M., \& Smart, C. (2004). Further evidence on the role of gender in financial performance. Journal of Small Business Management, 42(4), 395-417.

Cooper, A. C., Gimeno-Gascon, F. J., \& Woo, C. Y. (1994). Initial human and financial capital as predictors of new venture performance. Journal of Business Venturing, 9(5), 371-395.

Crant, M. J. (1996). The proactive personality scale as a predictor of entrepreneurial intentions. Journal of Small Business Management, 34(3), 42-50.

De Bruin, A., Brush, C. G., \& Welter, F. (2006). Introduction to the special issue: towards cumulative knowledge on women's entrepreneurship. Entrepreneurship Theory and Practice, 30(5), 585-593. 
Edwards, L., \& Field-Hendrey, E. (2002). Home-based work and women's labor force decisions. Journal of Labor Economics, 20(1), 170-200.

European Commission (2009). European Competitiveness Report 2009. Brussels: DG Enterprise and Industry.

Fairlie, R. W., \& Robb, A. M. (2009). Gender differences in business performance: evidence from the Characteristics of Business Owners Survey. Small Business Economics, 33, 375-395.

Florida, R. (2002). The rise of the creative class and how it is transforming work, leisure, community and everyday life. New York: Basic Books.

Fritsch, M. (2011). The effect of new business formation on regional development. Empirical evidence, interpretation, and avenues for further research. Jena Economic Research Papers 2011-006. Jena: Max Planck Institute.

Futagami, S., \& Helms, M. M. (2009). Emerging female entrepreneurship in Japan: A case study of Digimom workers. Thunderbird International Business Review, 51(1), 71-85.

Grilo, I., \& Irigoyen, J.-M. (2006). Entrepreneurship in the EU: To wish and not to be. Small Business Economics, 26(4), 305-318.

Gupta, V. K., Turban, D. B., Arzu Wasti, S., \& Sikdar, A. (2009). The role of gender stereotypes in perceptions of entrepreneurs and intentions to become an entrepreneur. Entrepreneurship Theory and Practice, 33(2), 397-417.

Jack, S. L., \& Anderson, A. R. (2002). The effects of embeddedness on the entrepreneurial process. Journal of Business Venturing, 17, 467-487.

Jacobs, J. (1984). Cities and the wealth of nations; Principles of economic life. New York: Random House.

Johnson, J. E. V., \& Powell, P. B. (1994). Decision making, risk and gender: Are managers different? British Journal of Management, 5(2), 123-138.

Kalleberg, A. L., \& Leicht, K. T. (1991). Gender and organizational performance: Determinants of small business survival and success. Academy of Management Journal, 34(1), 136-161.

Kitson, M., Martin, R., \& Tyler, P. (2004). Regional competitiveness: an elusive yet key concept? Regional Studies, 38(9), 991-999.

Klapper, L. F., \& Parker, S. C. (2010). Gender and the business environment for new firm creation. The World Bank Research Observer. doi:10.1093/wbro/lkp032.

Koellinger, P., Minniti, M., \& Schade, C. (2007). "I think I can, I think I can". Overconfidence and entrepreneurial behavior. Journal of Economic Psychology, 28(4), 502-527.

Koellinger, P., Minniti, M., \& Schade, C. (2008). Seeing the world with different eyes: Gender differences in perceptions and the propensity to start a business. Tinbergen Institute Discussion Paper TI 2008-035, Erasmus University Rotterdam, Rotterdam.

Kouriloff, M. (2000). Exploring perceptions of a priori barriers to entrepreneurship: A multidisciplinary approach. Entrepreneurship Theory and Practice, 25(2), 59-79.

Krueger, N., \& Brazeal, D. V. (1994). Entrepreneurial potential and potential entrepreneurs. Entrepreneurship Theory and Practice, 18(3), 91-104.
Krueger, N., \& Carsrud, A. L. (1993). Entrepreneurial intentions: Applying the theory of planned behavior. Entrepreneurship and Regional Development, 5, 330-351.

Krueger, N. F., Reilly, M. D., \& Carsrud, A. L. (2000). Competing models of entrepreneurial intentions. Journal of Business Venturing, 15(5-6), 411-432.

Langowitz, N., \& Minniti, M. (2007). The entrepreneurial propensity of women. Entrepreneurship Theory and Practice, 31(3), 341-364.

Lituchy, T. R., Bryer, P., \& Reavley, M. A. (2003). Small business in the Czech Republic and Japan: successes and challenges for women entrepreneurs. In H. Etemad \& R. Wright (Eds.), Globalization and entrepreneurship: policy and strategy perspectives (p. 152). Cheltenham : Edward Elgar.

Minniti, M. (2010). Female entrepreneurship and economic activity. European Journal of Development Research, 22(3), 294-312.

Minniti, M., \& Nardone, C. (2007). Being in someone else's shoes: the role of gender in nascent entrepreneurship. Small Business Economics, 28, 223-238.

Minniti, M., \& Naudé, W. (2010). What do we know about the patterns and determinants of female entrepreneurship across countries? European Journal of Development Research, 22(3), 277-293.

Minniti, M., Allen, E., \& Langowitz, N. (2006). The 2005 Global Entrepreneurship Monitor special topic report: Women in entrepreneurship. Babson College: Center for Women Leadership.

Mroczkowski, T. (1997). Women as employees and entrepreneurs in the Polish transformation. Industrial Relations Journal, 28(2), 83-91.

Naudé, W. A. (2010). Entrepreneurship, developing countries and development economics: New approaches and insights. Small Business Economics, 34(1), 1-12.

Niederle, M., \& Vesterlund, L. (2007). Do women shy away from competition? Do men compete too much? Quarterly Journal of Economics, 122(3), 1067-1101.

Okamuro, H., Van Stel, A. J., \& Verheul, I. (2010). Understanding the drivers of the 'entrepreneurial' economy: Lessons from Japan and the Netherlands, CCES Discussion Paper Series No.36, Center for Research on Contemporary Economic Systems, Hitotsubashi University, Tokyo.

Parker, S. C. (2009). The economics of entrepreneurship. Cambridge: Cambridge University Press.

Parker, S. C., \& Belghitar, Y. (2006). What happens to nascent entrepreneurs? An econometric analysis of the PSED. Small Business Economics, 27(1), 81-101.

Rabe-Hesketh, S., \& Skrondal, A. (2008). Multilevel and longitudinal modeling using Stata (2nd ed.). College Station: Stata Press.

Raspe, O., \& Van Oort, F. G. (2008). Firm growth and localized knowledge externalities. The Journal of Regional Analysis and Policy, 38(2), 100-116.

Reynolds, P., Bygrave, W. D., Autio, E., Cox, L. W., \& Hay, M. (2002). Global entrepreneurship monitor. London: Babson College, London Business School, and Kauffman Foundation.

Reynolds, P. D., Carter, N. M., Gartner, W. B., \& Greene, P. G. (2004). The prevalence of nascent entrepreneurs in the 
United States: Evidence from the Panel Study of Entrepreneurial Dynamics. Small Business Economics, 23, 263-284.

Saviotti, P. P. (1996). Technological evolution, variety and the economy. Cheltenham: Edward Elgar.

Sexton, D. L., \& Bowman-Upton, N. (1990). Female and male entrepreneurs: Psychological characteristics and their role in gender-related discrimination. Journal of Business Venturing, 5(1), 29-36.

Stam, E., Thurik, A. R., \& Van der Zwan, P. (2010). Entrepreneurial exit in real and imagined markets. Industrial and Corporate Change, 19(4), 1109-1139.

Van der Zwan, P., Verheul, I., Thurik, A. R., \& Grilo, I. (2009). Entrepreneurial progress: Climbing the entrepreneurial ladder in Europe and the US. Tinbergen Institute Discussion paper T12009-070/3, Erasmus School of Economics.

Van der Zwan, P., Thurik, A. R., \& Grilo, I. (2010). The entrepreneurial ladder and its determinants. Applied Economics, 42(17), 2183-2191.

Van der Zwan, P., Verheul, I., \& Thurik, A. R. (2011). Entrepreneurial ladder in transition and non-transition economies. Entrepreneurship Research Journal, 1(2), Article 4.

Van Stel, A. J., \& Suddle, K. (2008). The impact of new firm formation on regional development in the Netherlands. Small Business Economics, 30, 31-47.

Verheul, I., \& Van Stel, A. J. (2010). Entrepreneurial diversity and economic growth. In J. Bonnet, D. Garcia, \& H. van Auken (Eds.), The entrepreneurial society; How to fill the gap between knowledge and innovation (pp. 17-36). Camberley: Edward Elgar.
Verheul, I., Uhlaner, L. M., \& Thurik, A. R. (2005). Business accomplishments, gender and entrepreneurial self-image. Journal of Business Venturing, 20(4), 483-518.

Verheul, I., Van Stel, A. J., \& Thurik, A. R. (2006). Explaining female and male entrepreneurship at the country level. Entrepreneurship and Regional Development, 18(2), 151-183.

Verheul, I., Thurik, A. R., Grilo, I., \& Van der Zwan, P. (2012). Explaining preferences and involvement in self-employment in Europe and the United States: New insights into the role of gender. Journal of Economic Psychology. doi: 10.1016/j.joep.2011.02.009.

Watson, J. (2003). Failure rates for female-controlled businesses: Are they really any different? Journal of Small Business Management, 41(3), 262-277.

Welter, F., Smallbone, D., Aculai, E., Isakova, N., \& Schakirova, N. (2003). Female entrepreneurship in post-Soviet countries. In J. Butler (Ed.), New perspectives on women entrepreneurs (pp. 223-239). Greenwich: Information Age Publishing.

Wilson, F., Marlino, D., \& Kickul, J. (2004). Our entrepreneurial future: Examining the diverse attitudes and motivations of teens across gender and ethnic identity. Journal of Developmental Entrepreneurship, 9, 177-197.

Yang, J. Y., \& Li, J. (2008). The development of entrepreneurship in China. Asia Pacific Journal of Management, 25(2), 335-359.

Zhao, H. S., Seibert, S. E., \& Hills, G. E. (2005). The mediating role of self-efficacy in the development of entrepreneurial intentions. Journal of Applied Psychology, 90, 1265-1272. 